\title{
Selected Reference Books of 1965-1966
}

$\mathrm{T}$

HIS ARTICLE continues the semi-annual series ${ }^{1}$ originally edited by Constance M. Winchell. Though it appears under a byline the list is actually a project of the reference department of the Columbia University libraries, and notes are signed with the initials of the individual staff members. ${ }^{2}$

Since the purpose of the list is to present a selection of recent scholarly and foreign works of interest to reference workers in university libraries it does not pretend to be either well balanced or comprehensive. Code numbers (such as A11, 1A26, 2S22) have been used to refer to titles in the Guide ${ }^{3}$ and its supplements.

\section{BIBLIOGRAPHY}

British Museum. Dept. of Printed Books. Short-Title Catalogue of Books Printed in the Netherlands and Belgium and of Dutch and Flemish Books Printed in other Countries from 1470 to 1600 now in the British Museum. London: Trustees of the British Museum, 1965. 274p. 50 s.

With the publication of this list, the British Museum series of short-title catalogs now covers its holdings from "all those countries of the European continent where there was a considerable output of early printing." (Pref.) Thus, British Museum books published before 1601 in, and in the language of, France, Germany, Italy, Belgium and the Nether-

${ }^{1} C R L$, January and July issues starting January 1952. "Carol Anne Bondhus, Marilyn Goldstein, Rita Keckeissen, Evelyn Lauer, Hugh Macdonald, Sarah Ropes, Charlotte Smith.

${ }^{3}$ Constance M. Winchell, Guide to Reference Books (7th ed.; Chicago: ALA, 1951); Supplement (Chicago: ALA, 1954); Second Supplement (Chicago: ALA, 1956); Third Supplement (Chicago: ALA, 1960); Fourth Supplement (Chicagn: ALA, 1963). lands, Portugal, and Spain as well as Spanish America can be identified from their respective catalogs. As in earlier lists, entry is by author with abridged title, and the index is of printers and publishers.-R.K.

Enciclopedia de orientación bibliográfica. Director: Tomás Zamarriego. Barcelona: J. Flors, 1964-65. 4v.

Although titles in many languages and topics international in scope are considered, this annotated Spanish-language subject bibliography is definitely directed to Spanish interests. The subject arrangement, complemented by an author index, shows a heavy concentration in the areas of Roman Catholic theology and church history, and in the humanities. The necessity for selection in the face of the seeming avalanche of international literature requires careful discrimination and, while the editor offers the work to the nonspecialist as a study guide to the best material in all fields, the sciences and non-Hispanic letters do suffer. For the most part, the annotations are analytic rather than descriptive, and represent the work of an impressive array of Hispanic scholars.-C.A.B.

Grönroos, Henrik. Suomen bibliografisen kirjallisuuden opas. Guide des bibliographies finlandaises. Helsinki: Suomalaisen Kirjallisuuden Seura, 1965. 219p.

This bibliography of bibliographies on Finland includes works published up to December 1, 1965, in which a minimum of one chapter is devoted exclusively to Finland. Both separately published bibliographies and those appearing in books and periodicals are covered. There are four main divisions: general bibliog- 
raphies grouped by language; "Finland in foreign literature/Foreign countries in Finnish literature" arranged by country; specialized subject bibliographies; and bibliographies of individuals. Within sections the secondary arrangement is chronological by dates covered. Four indexes complete the work: subjects, names, authors, and anonymous works. Although the bibliography is chiefly in Finnish, the arrangement and indexes make its use relatively easy for persons not knowing that language; an additional help is the fact that the introduction and table of contents are in French as well as in Finnish.-S.R.

Paris. Bibliothèque Nationale. Département des Imprimés. Catalogue général des livres imprimés: auteurs-collectivités-auteurs-anonymes, 1960-1964. Paris: 1965- . v.1- . (To be in 12v.)

Contents: v.1, A-Bic. 996p.

Beginning with v.187, the Catalogue général of the Bibliothèque Nationale has included imprints through 1959 only. This is the first volume of the promised quinquennial supplements-a welcome series on several counts. It records additions for the 1960-64 period, and therefore includes (as do the "Additions" volumes of the British Museum catalog) some works of earlier date, though nonFrench items published prior to 1960 are largely excluded. Unlike the basic cata$\log$, the supplementary series includes corporate entries and title entries for anonymous and collective works. There are added entries for joint authors, translators, etc. Separate series are planned for works in Cyrillic characters, works in Modern Greek, and works in Hebrew characters.-E.S.

Peeters-Fontainas, Jean F. Bibliographie des impressions espagnoles des PaysBas méridionaux. Nieuwkoop: B. de Graaf, 1965. 2v. \$50.

This bibliography comprises works by Spanish authors which were produced from 1520 to 1785 in presses of the Pays-
Bas méridionaux (the Spanish Netherlands). Covering such diverse subjects as devotional texts and accounts of voyages of discovery, the work is arranged alphabetically by author or anonymous title. Entries are numbered, and include full bibliographical data, descriptive notes, and locations of copies. For each author, the complete works are given first, followed by individual ones arranged by title; works with the same anonymous title are listed chronologically. The first volume contains a comprehensive list of works consulted, and at the end of the second volume are added appendices on additional findings, a series of illustrations of printers' marks, and a chronological table serving as a kind of index to the editions cited. The bibliography was painstakingly compiled and should be of great value to scholarship in the history of the book and of printing.-M.G.

\section{Microforms}

National Register of Microform Masters. Sept. 1965- . Washington: Library of Congress, 1965- . Irregular. Included in NUC subscription.

Two basic purposes are outlined for this new service: (1) to provide a complete national listing of microform master negatives from which libraries may acquire prints in single copies, thus avoiding expensive duplication of masters; and (2) to identify those negatives which are stored under particular conditions to insure preservation. Foreign and domestic books, pamphlets, serials, newspapers, and foreign dissertations are included, but not technical reports, typescript translations, foreign or American manuscripts, American doctoral dissertations and masters' theses. Titles for which Library of Congress or National Union Catalog cards are available are arranged by card number, the remainder alphabetically. Locations are indicated by library symbols, followed by symbols indicating form of the master. The Register is concerned solely with master micro- 
forms retained for the purpose of making copies, not with those that may be used by readers.-C.S.

\section{LIBRARIES}

Lewanski, Richard Casimir, comp. Subject Collections in European Libraries; a Directory and Bibliographical Guide. New York: Bowker, 1965. 789p. \$25.

Title also in French, German, Italian, Russian, and Spanish; prefatory matter in English, French, and German.

Designed as a companion to Lee Ash's Subject Collections ... . in the U.S. and Canada (2d ed., N.Y., 1961), this work covers subject collections in northwestern Europe primarily, and a limited number in other parts of Europe, excluding Asiatic parts of the Soviet Union and Turkey. Approximately eight thousand collections in six thousand libraries are represented, but coverage is very uneven, information having been derived from questionnaires in some instances and from published directories in others. Entries include address of library, name of director, size of the special collection, and restrictions on use. Instead of the alphabetical subject arrangement used in the Ash volume, the language problem has dictated use of the Dewey Decimal Classification; abridged classification tables and brief indexes are provided. The arrangement, plus the uniformity of the typography, does not lend itself to easy scanning or quick reference, yet the guide is welcome as an initial effort in this area.-C.S.

\section{Periodicals}

Index to Little Magazines, 1943-1947. Comp. by Stephen H. Goode. Denver: Alan Swallow [c1965], 287p. \$7.50.

Continuing retrospectively the work begun in 1948 by Alan Swallow, et al., this author-subject index of a selected list of little magazines not indexed elsewhere covers the years 1943-1947. It is the first of an anticipated ten-volume series to be concerned with the complete range of American little magazine activity from 1900 to 1948 . As in previously published volumes, subject headings are kept at a minimum, using personal names especially and broad topical categories. In this volume, subjects are distinguished from author entries by upper case letters. The exclusion of citations for editorials, graphic art, and book reviews are the principal variations from the volumes covering more recent years. The list of magazines indexed includes neither place of publication nor the numbers of the volumes or issues indexed.-M.G.

\section{Union List of Serials in Libraries of the}

United States and Canada. 3d ed. Edna Brown Titus, ed. New York: H. W. Wilson, 1965. 5v. \$120.

"Under the sponsorship of the Joint Committee on the Union List of Serials with the cooperation of the Library of Congress, funded by a grant from the Council on Library Resources, Inc."

Few reference works of recent years can have been more eagerly awaited or more welcomely received than this third edition of the Union List of Serials. While, as is generally known, it does not advance the period of coverage of the second edition and its supplements, it does list nearly twelve thousand additional titles which began publication before 1950. Thus, 156,449 serials held in 956 libraries in the U.S. and Canada are now represented. Entries from the second edition and supplements were combined and carried over without change "except in those instances where reports of bibliographical changes in title were investigated and additional locations supplied." Deletions of holdings were made only where expressly requested. Harold Rovelstad, chairman of the joint committee, has contributed a preface giving a brief history of union lists and some in- 
teresting remarks on the mechanics of preparing this third (and, alas, most probably last) edition.-E.S.

\section{MASTER's THeses}

Black, Dorothy M. Guide to Lists of Master's Theses. Chicago: ALA, 1965. 144p. $\$ 5.25$.

Perhaps no other type of material is as troublesome to the interlibrary loan librarian as the master's thesis. This work is offered as a help in verifying and improving citations for interlibrary loan requests, as well as an aid to research at the graduate level. It deals only with printed sources, incorporating references from Palfrey and Coleman (Guide G8) as appropriate. There is a section of lists of master's theses in subject fields, and another of lists from specific institutions. Descriptive annotations are provided, and the information on lists issued in series is remarkably detailed.-E.S.

\section{ReLIGION}

\section{The Encyclopedia of the Lutheran} Church. Julius Bodensieck, ed. Minneapolis: Augsburg Publishing House, 1965. 3v. $\$ 37.50$.

Sponsored by the Lutheran World Federation, this encyclopedia may be considered an authoritative "description" of Lutheran doctrine, history, and activity. Each of the seven hundred contributors is responsible for the articles bearing his signature, and the standards of scholarship are high. The articles are generally written from an historical rather than an analytical point of view; some offer an appended bibliography. The scope of the title is broadened to the extent that brief descriptions of other religions, beliefs, and cultures are included as a frame of reference. This encyclopedia serves well as a convenient reference work on Lutheranism, and students and researchers in many fields may find it useful as a preliminary guide.C.A.B.

\section{Sociology}

Davis, John P. The American Negro Reference Book. Englewood Cliffs, N.J.: Prentice-Hall, 1966. 969p. \$19.95.

The purpose of this work is to provide "a reliable summary of current information on the main aspects of Negro life in America, and to present this information in sufficient depth to provide the reader with a true perspective." (Pref.) Intended for consecutive reading as well as for reference, the volume consists of twenty-five essays written by specialists, and dealing with the social, cultural, and economic life of the Negro. From the reference point of view, its chief merits lie in the bibliographic references contained in the footnotes and following each chapter, and in the very extensive and noteworthy index. The latter runs to eighty-eight pages and includes numerous cross references and identifying notes.-C.S.

Encyclopedia of U.S. Government Benefits. R. A. Grisham, Jr., ed. Union City, N.J.: Wm. H. Wise, 1965. 1001p. \$7.95.

The Introduction promises that this book "includes all the services and benefits provided by the government and will help [the citizen to understand his] relationship to his government." It provides an alphabetical list of benefits and government programs which should be useful for general reference, but is very uneven in coverage and one notes errors and inconsistencies in the compilation. Some articles, such as "Social Security," are very long and detailed, while others are too short to be useful and do not say how or where to apply for benefits. In some cases short articles are repeated within other articles: e.g., "Fellowships, National Defense Education Act" is reprinted at the beginning of "National Defense Education Act Fellowships." Another irregularity is the incomplete cross referencing from names of indi- 
vidual national parks to the general article where each is described. A good point is the great quantity of photographs, but even these seem to be more decorative than instructive.-S.R.

Texas. University. Population Research Center. International Population Census Bibliography: Latin America and the Caribbean. Austin: University of Texas, Bureau of Business Research, 1965. various pagings. $\$ 3$. (Census bibliography, 1)

First in a series which aims to provide a universal bibliography of census reports, this volume covers Latin America and the Caribbean. (Nos. 2 and 3 of the series, dealing with Africa and Oceania respectively, have also appeared, and follow the pattern of the first.) The bibliography mainly consists of listings of separately-published population census reports, though other types of series (e.g., housing and agriculture) are included if population data are included therein. Arranged alphabetically by area and then chronologically, entries frequently include national, provincial, state, and city censuses from colonial times to the present, with listing of sources, scope notes, and analyses of sets. There are also indications of censuses taken but not published. Although the table of contents is adequate for the main areas cited, there is no index-an aid needed for the smaller areas and types of information provided.-M.G.

Welsch, Erwin $\mathrm{K}$. The Negro in the United States: a Research Guide. Bloomington: Indiana University Press, 1965. 142p. $\$ 1.85$ paper; $\$ 5$ cloth.

In this "critical introduction," designed to include "almost all areas of involvement which could conceivably be the subject of an introductory inquiry" (Foreword), the author has tried to select the best, or most important works for inclusion. Four main divisions-science, philosophy and race; historical and sociological background; major issues today; the Negro and the arts-are given subdivision appropriate to the matter. Books, periodicals, and essays are included with comment, usually descriptive and critical. Citation is brief, full information (including price for in-print books) being listed in a bibliography which serves also as an author index. Subject index and analytic table of contents facilitate use.-R.K.

\section{Political Science}

Metron Inc., New York. Universal Reference System. International Affairs. Prepared under the direction of Alfred de Grazia. New York: ${ }_{[}$c1965 . 1205p. $\$ 29.95$. (Political science, government and public policy series, no. 1)

Subtitle: An annotated and intensively indexed compilation of significant books, pamphlets, and articles, selected and processed by the Universal Reference System-a computerized information retrieval service in the social and behavioral sciences.

This computer produced index of 3030 items is the first of an ambitious series designed to cope with the social science literature explosion by providing intensively indexed materials "above a modest level of quality" for "maximum research satisfaction." (Introd.) The selection is of classics and twentieth-century writings with heavy representation for publications of the last three years; all social and behavioral sciences are included. Two listings make up the work: the Catalog, which lists items in an arbitrarily assigned numerical order with complete bibliographical information, descriptive annotation, and all the descriptors which characterize the work; and the Index of Documents, which is the means of access to the Catalog. The Index section is an alphabet of index 
terms (descriptors from the Universal Reference System) with entries under each term grouped by form and then by date. All descriptors assigned a document are given and the Catalog item number to which reference is being made. Writings average twenty descriptors and have from ten to twenty listings in the Index to make them "thoroughly retrievable." A distinctive feature is that descriptors apply not only to content, but to method as well. An author index is appended.-R.K.

\section{LAw}

Kling, Samuel G. The Complete Guide to Everyday Law. Chicago: Follett Publishing Company, 1966. 624p. $\$ 6.95$.

Written by an experienced lawyer, this book is a layman's guide to basic law of such topics as marriage and divorce, sales, real estate, veterans' benefits, contracts, wills, social security, and other areas of general interest. The clear question-and-answer method of coverage, complemented by tables which specifiy the practice of individual states, provides a handy outline to the principles of law. The selection of a lawyer, his fees, and his function in the court are discussed in the opening chapters of the volume, and a glossary of terminology and a selection of legal forms supplement the text. The nontechnical language and the practical nature and arrangement of the subjects included make this quite a useful guide through the technicalities of everyday legal matters.-C.A.B.

\section{Treaties}

Harvard University. Law School. Library. Index to Multilateral Treaties; a Chronological List of Multi-party International Agreements from the Sixteenth Century through 1963, with Citations to Their Text. Vaclav Mos- tecky, ed. Cambridge, Mass.: 1965. 301p. \$13.

The traditional definition of "treaty" has here been expanded to include international agreements among organizations, as well as among governments. This heterogeneous list is selective, confining itself to those documents signed by three or more nations. However, the Index does conveniently extend the coverage of the U.S. Department of State Catalogue of Treaties, 1814-1918 (1919; Guide L653), and, like that volume offers citations to sources for the complete text (official, if possible) of the treaties. The entries also include such data as catchword subject description and names of participating parties. The volume is supplemented by a "Subject and Regional Guide" which serves as a general index.-C.A.B.

\section{LiNGUistics}

Akademiia Nauk SSSR. Institut Russkogo Iazyka. Strukturnoe $i$ prikladnoe iazykoznanie; bibliograficheskii ukazatel literatury, izdannoi v SSSR $s 1918$ po 1962 g. Moskva: Nauka, 1965. 193p. $1 r ., 3 k$.

According to the preface, this is the first index to the literature of structural and applied linguistics, either in the Soviet Union or abroad. Limited to materials published in the USSR in both Slavic and non-Slavic languages, it includes books; dissertations; articles from journals, serial publications, and anthologies; and reviews. Newspaper articles are excluded. The editors report that all items have been examined before being assigned to the classified arrangement. A separate list of books and articles published abroad in foreign languages, but which were the subject of Soviet reviews is included, along with an abbreviations list and a list of non-Russian periodicals published in the USSR and referred to in the text. There is a name and title index.-E.L. 


\section{DiCTIONARIES}

Filin, Fedot Petrovich. Slovar' russkikh narodnykh govorov. Leningrad: Nauka [Leningradskoe otd-nie], 1965- . v.1- . Contents: v.1, A-Aia. 302p.

Covering the nineteenth and twentieth-century vocabulary of Russian dialects, this dictionary will be one of a number of dictionaries which are projected to cover all aspects of the Russian language. It attempts to include all Russian dialects, even those spoken in foreign-language areas, and also to note those features of Russian dialects which have fallen into disuse or are now only weakly preserved. The entries give the pronunciation, meaning, region of origin, and use of each word, as well as pattern sentences and references to sources. Half of this first volume is given over to an extensive bibliography of manuscript and printed sources, plus a list of administrative and geographical regions and their abbreviations.-E.L.

Haugen, Einar Ingvald. Norwegian English Dictionary. Oslo, Universitetsforlaget; Madison: Univ. of Wisconsin Press, [1965]. 500p. \$12.50.

Intended for the student of Norwegian, and containing many features not found in other Norwegian-English dictionaries, this should be a useful addition to reference collections. Forms of Norwegian, Dano-Norwegian, and New Norwegian are listed in a single alphabet. Definitions are given in American English and are often labeled as to usage (archaic, humorous, etc.). Common abbreviations, important place and proper names, and cultural features have been listed in the main alphabet. Cross references are made from variant spellings to that which is currently official, and irregular, nonlexical forms are also cross referenced. The introduction, which is in English, is especially useful. It offers instructions on the use of the dictionary, a history of the Norwegian language, a pronunciation guide, and a bibliography of more than seventy other dictionaries and word lists. Typographically the pages have a crowded appearance, but this defect is more than compensated for by the unusually thorough coverage.S.R.

\section{Agriculture}

Boalch, Donald Howard, ed. Current Agricultural Serials; $a$ World List of Serials in Agriculture and Related Subjects (Excluding Forestry and Fisheries) Current in 1964. Oxford: International Association of Agricultural Librarians and Documentalists, 1965- . v.1- .

Contents: v.1, Alphabetical list. 351p.

More than twelve thousand four hundred serials "current in the summer of 1964, dealing with agriculture and kindred subjects" (Pref.) are entered alphabetically by title or corporate body in this first volume of a projected twovolume work. Since the range of "kindred subjects" is broad, there is a certain coincidence of listings here and in the World List of Scientific Periodicals, but, as a current subject list rather than a union list, the new work should prove useful. New or changed titles will be reported in the Quarterly Bulletin of the International Association of Agricultural Librarians and Documentalists, thus insuring currency. As far as possible, title, place of publication, starting-year, frequency, publisher, and UDC number are indicated for each serial. An index of UDC numbers in English, French, German, and Russian is given at the end of the volume. The second volume, to appear in 1966, will provide "a UDC and quadrilingual index, by subject and place of origin." (Pref.)-E.S.

\section{Theater and Cinema}

Bessy, Maurice and Chardans, JeanLouis. Dictionnaire du cinéma et de la télévision. Paris: Jean-Jacques Pauvert, 1965- . v.1- . 
Contents: v.1, A-C. 520p. 96F.

With the increasing focus of scholarly attention on the cinema as an art form, there is need for reference works to provide the basic information which students will require in their research. When complete in five volumes (with "filmographie" or list of film titles), the Bessy and Chardans work should prove a considerable step in this direction. The dictionary does not include true biographies of film and television personalities, but the entries under personal names, in addition to giving brief identifying statements, attempt to list chronologically all of an individual's film appearances. These entries constitute a considerable part of the work and are useful primarily for motion pictures, television work not being well reported. Photographs are scattered profusely throughout and are of varying degrees of usefulness, most being very small. Volume one contains some long and basically technical articles such as "Camera" and "Censure"; an article on "Affiches" (Posters) gives an historical survey reaching back well before the advent of the cinema. But the dictionary is strongest by far in history of cinema technology-ranging from production equipment and methods to theater construction and maintenance. Altogether, the work supplies a great deal of information not easily found elsewhere, making this an almost indispensible work for the cinematic sciences despite the uneven coverage of television.-H.M.

Rigdon, Walter, ed. The Biographical Encyclopedia of Who's Who of the American Theatre. New York: J. H. Heineman, [1966, c1965]. 1101p. $\$ 82.50$.

To present as complete as possible a picture of the American theater, past and present, is the goal of this encyclopedia. The main section is a selective, alphabetical list of 3350 biographies of
American and European actors, directors, playwrights, designers, teachers, and others who have made notable contributions to the American theater. Supplementing this is a "Necrology," international in scope, listing over nine thousand people with place and date of birth and death. To complete the historical picture are a list of plays produced in New York since 1900, with the name of the theater, opening date, and number of performances for each; complete playbills for 1959-64 of Broadway, off-Broadway, and leading United States repertory companies; and a chronological listing of American plays which received their first professional production abroad. Also useful are the lists of American theater awards and their recipients. Two bibliographies are included: one of theater recordings; another of biographies. This is an indispensible tool for theater and research libraries.-S.R.

\section{LITERATURE}

Cioranescu, Alexandre. Bibliographie de la littérature française du dix-septième siècle. Paris: Centre National de la Recherche Scientifique, 1965- . v.1- . Contents: v.1, Généralités; A-C. 666p. $90 \mathrm{~F}$.

In effect, a continuation of the same author's bibliography covering the sixteenth-century (Suppl. 4R106), and offered with the hope that another will follow for the eighteenth, this bibliography is concerned with truly literary works. While the sixteenth-century was covered in one volume which included a comprehensive index, this is the first of several volumes and will have an index in the last only. Otherwise the format is largely similar to that of the earlier work: a general section with subdivisions for history of the book, literary history, social and religious background, literary forms, etc., followed by bibliographies of individual authors. Future volumes will continue the author 
alphabet, which lists an author's own works followed by critical studies on an international level. More comprehensive than the corresponding Cabeen volume (though without annotations), the bibliography remains selective but offers rich material. Until the index appears it may be somewhat difficult to get at the diversified information in the first section, but once complete, the set should be highly useful to scholars in this field. -M.G.

Jahn, Janheinz. Die neoafrikanische Literatur; Gesamtbibliographie von den Anfängen bis zur Gegenwart. [Düsseldorf]: E. Diederichs Verlag, [1965]. 359p. \$12.50.

Also published under title: A Bibliography of Neo-African Literature from Africa, America, and the Caribbean (New York: Praeger, 1965).

Captions and introductory material in German, English, and French.

Here is a rather curious bibliography of an area of literature that still needs to be better defined, though the compiler promises to do so in a forthcoming book. The present work is apparently not strictly limited to those works which would exhibit Jahn's as yet unspecified "stylistic elements of neo-African literature," but it should be generally useful as a list of literary works by Negroes in Africa, the Americas, and the Caribbean (but excluding North Africa, Europe and Australasia). Arrangement is by area, the two great divisions being Africa and America. In addition, there is a section for anthologies and one for literary forgeries. One notes considerable emphasis on very recent works and contemporary authors, but a book by Ioannes Latinus as early as 1573 is included. There is an author index, but another of titles would increase the value of the book. Altogether, this is a fair bibliography for a literature now emerging into real importance.-H.M.
Kindlers Literatur Lexikon. Zurich: Kindler Verlag, [1965- ]. v.1- . (To be in $7 \mathrm{v}$.) $\$ 37.50$ per v. (SwF165,40). Contents: v.1, A-Cn. $2710 \mathrm{col}$.

Although inspired by Bompiani's Dizionario letterario (Guide R31), this is an altogether new work, and a significantly more useful one than either the Bompiani or the French adaptation thereof (Dictionnaire des oeuvres ....; Suppl. 3R7). In addition to the brief history of a work and the précis of its plot that Bompiani provides, Kindler furnishes an excellent short bibliography at the end of each article, listing, when appropriate, first edition, standard editions, adaptations (dramatic or operatic), critical works, and translations. Since most titles are entered in the original language, the Lexikon serves even the person who does not read German as a quick bibliographic source on any notable work in world literature. Titles in Eastern as well as Western literature are covered-though not with the same degree of comprehensiveness-and there is a certain emphasis on the works of living authors. In all, good bibliographies, the broad range of the work, and its lavish format (good paper, clear type, and beautiful color plates) make this a welcome reference tool. A separate index will be issued with each volume until the cumulated index is published in the final volume.-H.M.

Smirnov-Sokol'skii, Nikolai Pavlovich. Russkie literaturnye almanakhi $i$ sborniki XVIII-XIX vv.; [bibliografia]. Moskva: Kniga, 1965. 590p. 3r., 30k.

In 1956 the author published a bibliography of the same title (Suppl. 3R131), with the designation "preliminary list." Now the complete edition appears, containing more than three hundred additional listings and offering bibliographic and historical information on literary anthologies of the eighteenth and nineteenth centuries. Three different 
kinds of anthologies are represented in one chronological sequence: general collections of literary miscellany, collections of humor, and children's anthologies. Wherever possible, information concerning the editorial history and a list of the contents are given for each anthology. An essay on the history of Russian literary anthologies of the period, illustrations, and two indexes (one of titles; the other of authors of individual items) enhance this well organized work.-E.L.

Temple, Ruth Zabriskie and Tucker, Martin, eds. A Library of Literary Criticism: Modern British Literature. New York: Ungar, [1966]. 3v. \$30.

This work, similar in plan to Nyren's A Library of Literary Criticism: Modern American Literature (Suppl. 4R40), covers more than four hundred twentieth-century British writers, giving for each excerpts from criticism bearing on his qualities, status, and "if he is well known, something of his life and personality." (Introd.) Arrangement is alphabetic by author treated, with criticisms in chronological order, a plan that often serves to illustrate fluctuations in literary reputation. Excerpts have been drawn from both books and articles, and exact sources are noted. The Introduction, besides stating policies and principles of compilation, surveys the British reviewing scene of the past half century. Bibliographies of an author's own works appear at the end of the volume; a "crossreference index to authors" indicates significant mention of writers within the critical selections, and an "index to critics" draws together all selections of one writer in this compilation.-R.K.

\section{BIOGRAPHY}

Australian Dictionary of Biography. Melbourne: Melbourne University Press, 1966-.v.1- .

Contents: v.1, 1788-1850, A-H. 578p. $\$ 12$ Aust.
Supported in a variety of ways on a national basis, this new biographical dictionary is planned as a scholarly work based on consultation and cooperation. "The burden of writing has been shared almost equally by university historians and by members of historical and genealogical societies and other specialists." (Pref.) Most articles are signed, but there are unsigned articles, usually prepared by the Dictionary staff. Citations to published or manuscript sources are provided. As with the new Canadian biographical series noted below, chronological division has been established: there are to be two volumes for the 1788-1850 period; four volumes for the 1851-1890 period; and probably six volumes for 1891-1938. "The placing of each individual's name in the appropriate section has been generally determined by when he did his most important work. ... For articles that overlap the chronological division, preference has usually been given to the earlier period." (Pref.) Some six thousand articles are to be included. While most entries are of obvious significance, some names in the early period were chosen merely as examples of the "Australian experience." A provisional list of names for the next period will be inserted in the final volume of each of the first two sections to serve as a guide until a complete index is published.-E.S.

Dictionary of Canadian Biography. Toronto: University of Toronto Press, 1966- . v.1- .

Contents: v.1, 1000 to 1700.755 p. $\$ 15$.

Since the establishment of the "D.C.B." in 1952, scholars, researchers, and librarians have looked forward to the publication of this new work. The editors are striving to produce a complete dictionary of national biography "which should supply full, accurate and concise biographies of all noteworthy inhabitants of the Dominion of Canada 
(exclusive of living persons), from the earliest historical period to the time of publication." (Gen.Introd.) The new dictionary differs from the D.N.B. in having a "period arrangement": each volume will be self-contained and will cover a specific number of years, with the biographies arranged alphabetically within the period. While the chronological arrangement does not lend itself as readily to quick reference as does the single alphabet, it is useful in giving an historical perspective. Introductory essays and an index of names mentioned in the text are also helpful in this respect.

Volume I covers maritime explorers, Indians, and people of New France, Acadia, Hudson's Bay Colony, and Newfoundland. The 594 signed biographies in this volume are mainly in the 300 1000 word range, and are generally shorter than those projected for later volumes. Bibliographies are appended. A French-language edition is being published simultaneously, articles being written in French or English according to the writer's preference, then translated for the alternate edition.-C.S.

Renouard, Philippe. Imprimeurs \& $l i$ braries parisiens $d u \quad X V I^{\mathrm{e}}$ siècle: ouvrage publié d'après les manuscrits de Philippe Renouard par le Service des Travaux Historiques de la Villa de Paris avec le concours de la Bibliothèque Nationale. Paris: 1964- . v.1- .

Contents: v.1, Abada-Avril. 367p., plates. $200 \mathrm{~F}$.

Edited from the manuscripts of the master printer and scholar Philippe Renouard (1862-1934), this is the first volume in a series to be devoted to the careers and production of sixteenth-century Parisian printers and booksellers. When completed, it will serve as a bibliography of Parisian imprints of the period and will offer a considerable contribution to knowledge of the French
Renaissance and early urban history. Primarily a biobibliography, this first volume includes citations to materials in 234 libraries in France and nine foreign countries. Each entry has a biographical notice, often followed by references to documents and unpublished archival materials. Listings for printers predominate, and contain chronologically descriptive notes on their editions. Plates at the end of the volume illustrate the various printers' typographic traits. There is a detailed subject index. The completed work will be useful in both the biographical and bibliographical fields.M.G.

\section{Geography}

Monkhouse, Francis John. A Dictionary of Geography. London: Edward Arnold, 1965. 344p. 35s.

Some three thousand four hundred terms used in specific geographical context are included here in a clear and compact format. The emphasis is on specific, factual information, but the definitions are supplemented by statistics, formulae, and diagrams: e.g., under the pertinent entries, ocean areas and depths, longest rivers, and altitudes of mountains are given. Foreign words are listed where accepted in English, and special attention is given to variations in American and English usage. Etymologies and derivations are not given in detail, and political names, countries, cities, regions, etc., are omitted. At back is an analytical list of entries (among the categories are Landforms, Oceanography, Climate, Cartography, and Archaeology) which defines the scope of this useful work.-S.R.

The Times, London. The Times Indexgazetteer of the World. London: The Times Publishing Co., Ltd., 1965. 964p. \&10.

Essentially a companion to the Times Atlas of the World (Suppl. 2U29, etc.) 
as a location guide for the three hundred forty-five thousand geographical features listed in the volume, this new work is not a descriptive gazetteer and its other uses are limited. Each listing is identified by political entity and located by latitude and longitude, with reference to a Times map in most cases. However, the feature can be located on any map upon which it is possible to plot accurately longitude and latitude; these coordinates are given to the nearest minute. The volume could also be of help in establishing a standard spelling for a geographical name, since there are cross references from alternate spellings to that currently used (1965) by the government in power. Spot checking indicates that the index is exceedingly thorough in its listings for any well mapped area of the world.-H.M.

\section{HisTORY}

Akademiia Nauk SSSR. Institut Istorii. Istorii istoricheskoi nauki $v$ SSSR; do oktiabr'skii period. Bibliografiia. Moskva: Nauka, 1965. 702p.

The scope of this bibliography is historiographical literature dealing with the prerevolutionary history of, and published in, the territories now comprising the USSR. It includes books, articles, essays from collections, dissertations, and some items from newspapers. Special attention is focused on the prerevolutionary Lenin era and the contributions to historiography made by the members of the nineteenth-century radical and revolutionary movements. Citations are grouped in a subject classification scheme of which the three main divisions are: (1) general historiography; (2) literature about the activities of institutions and societies in the field of history; and (3) literature about regional historians. A detailed index facilitates use.-E. L.

Dahlmann, Friedrich Christoph. Dahl-
mann-Waitz. Quellenkunde der deutschen Geschichte; Bibliographie der Quellen und der Literatur zur deutschen Geschichte. 10. aufl. Hrsg. im Max-Planck-Institut für Geschichte von Hermann Heimpel und Herbert Geuss. Stuttgart: A. Hiersemann, 1965- . Lfg.1- . Approx. $\$ 350$ the set. Contents: Lfg.1, Einleitung, Verzeichnis der allgemeinen Abkürzungen, Verzeichnis der Sigel; Lfg.2, Abschnitt 393: 8 Buch, Allgemeines; Abschnitt 394; 8 Buch, Weltkrieg und Versailles 1914-1919 (Anfang). DM 25 per Lfg.

Long recognized as the standard bibliography for German history, the 9th edition of Dahlmann-Waitz appeared in 1931 (Guide V252). This new edition is to be in six volumes, and publication will be spread over the next several years. Coverage is extended to the end of World War II, and includes works published through 1960. The general plan of the work remains the same: a general section, and a chronological section by historical periods. On the basis of the single fascicule of bibliography received (sections are being published as completed rather than in sequence of coverage), plus comparison of the table of contents of the 9th edition with the outline for the 10th, substantial reworking of the various sections is indicated. The publisher's announcement estimates three times as many entries for the new edition, and a greater number of nonGerman writings is to be included throughout. All the same, since numerous citations are evidently being dropped, librarians may well wish to keep the 9th edition in the reference collection.-E.S.

Johann Gottfried Herder Institut, Marburg. Bibliothek. Alphabetischer Katalog. Boston: G. K. Hall, 1964. 5v. \$250.

The Johann Gottfried Herder Institut was established in 1950 "for the purpose of scholarly research on those countries 
in which German and Slavic peoples lived in proximity for many centuries" (Foreword), and the holdings of its library cover not only writings on the cultures of the East Central European states, but also important works on the Soviet Union, Finland, and West Germany. These volumes reproduce the library's card catalog, with entries (authors and some subjects) for approximately seventy thousand volumes, including one thousand one hundred current serials, dealing with "the territory itself; the inhabitants and all their activities through the course of history, from prehistoric times to the present; and all aspects of cultural life." Works on the natural sciences, technology, and medicine are excluded. As a listing of works on the cultures of East Germany, Estonia, Latvia, Lithuania, Poland, and Czechoslovakia it should be especially useful.-C.S.

Kuehl, Warren F. Dissertations in History; an Index to Dissertations Completed in History Departments of United States and Canadian Universities, 1873-1960. Lexington, Ky.; University of Kentucky Press, 1965. 249p. $\$ 12.50$.

A welcome addition to the growing corpus of dissertation bibliographies in various disciplines, this volume lists more than seventy-five hundred doctoral dissertations from the history departments of some eighty universities for the long span of years designated in the subtitle. Dissertations dealing with historical topics, but submitted in departments other than history are not included. Entries are arranged alphabetically by author, and for each are given the author's full name, dissertation title, university, and year. A "numerical summary" lists universities covered, date of first history degree, number of degrees conferred, and sources consulted. The long subject index, described as "stan- dard in form following in general the pattern in the ... Guide to Historical Literature" (p.211), is a combination of standard subject headings and important key words from the dissertation titles.R.K.

Lexikon der alten Welt. [Hrsg. von Carl Andresen et al.] Zürich, Stuttgart: Artemis Verlag, 1965. 3524 col. DM 280.

For classical scholars and students of antiquity, this work will be a welcome complement to the Oxford Classical Dictionary (Oxford, 1949). Unlike the older work, this volume does not limit itself strictly to Greco-Roman civilization, but includes material on the Orient when related to Western culture, and also on early Christianity. Two hundred and thirty-seven scholars have contributed signed articles in the areas of literature, philosophy, political and cultural history, religion, law, economics, technology, and communications. Detailed cross references and the inclusion of up-todate bibliographies in individual articles expand the usefulness of the work, while maps, charts, and drawings enhance the text. Additional features include a list of illustrations depicting persons mentioned in the articles, descriptions of famous Greek and Latin manuscripts and papyri, chronologies of the most important archaeological excavations, and translations of selected Greek and Latin quotations. There is also an extensive abbreviations list, a list of place names with reference to locations on maps in the volume, and an index of Greek and Latin terms with their German equivalents.-E.L.

Polska Akademia Nauk. Instytut Historii. Bibliografia historii Polski. Pod red. Heleny Madurowicz-Urbańskiej oprocowali Wiesław Bieńkowski [et al.]. Warszawa: Państwowe Wydawn. Naukowe, 1965- . v.1, pt. 1- . 
Contents: v.1,pt.1, Do roku 1454. 759p., zł.155; v.1,pt.2, 1454-1795. 399p., zt.86.

These two parts make up Volume I of what is to be a three-volume bibliography of Polish history from earliest times to 1944. The first section of part one is a general guide to bibliographic and reference aids, methodology, historiography, archives and libraries, and auxiliary studies; it is followed by bibliography of Polish history arranged by periods to 1454 , with appropriate subdivisions. Volume I, part 2, continues the period sections to 1795 . (Volume II will deal with Polish history to 1918, and Volume III that of the years following.) While coverage extends to such subjects as statistics, economics, and sociology, the bibliography is meant to be selective rather than exhaustive. Both books and periodical materials are included; the great bulk of entries is, understandably, in Polish. There are some brief annotations and cross references; items are numbered; and an author index is promised.-E.S.

Répertoire méthodique de lhistoire moderne et contemporaine de la France. v.8, Années 1907, 1908 et 1909. Paris: Editions du Centre National de la Recherche Scientifique, 1965. 241p. $20 \mathrm{~F}$.

After an unusual number of delays and vicissitudes this volume, edited from the original research of Pierre Caron and his associates, appears to fill the gap in the series (Guide V235) so that it now offers consecutive coverage for the 18981913 period. The classified arrangement with indexes of authors and persons and of places is consistent with that of the previously published volumes.-E.S.

\section{CHURCH HISTORICAL COLLECTIONS . . .}

(Continued from page 303 )

working with the collection is not a professional librarian, basic rules of filing, cataloging, classification, and preservation must be mastered.

One of the most important things would seem to be to establish a set of rules and organizational procedures to be followed. No collection should be allowed, like Topsy, simply to grow. A mass of unorganized materials is of little value to anyone.

Patrick Henry once said, "I know of no way of judging of the future but by the past." 43 If this be true, it can be concluded that if the various church bodies are to progress in the days to come, they must know their history and heritage. A collection of church historical materials is essential to such knowledge.

4 Patrick Henry, "American Liberty," Great Americans Speak ...., ed. by F. C. Packard (New York: Scribner, ${ }_{[}^{1951_{]}}$), p. 2.

\section{JUNIOR COLLEGE . . .}

\section{(Continued from page 266)}

The people who met in May recommended to their respective boards that a continuing joint committee of AAJC and ALA be established to give leadership to such projects and that some full-time staff services be made available to the committee.

This presentation started with an emphasis upon the importance of communication in the learning process. The events just reported lead to the happy conclusion that communication is improving between professionals who have somewhat different responsibilities on the campus but a common interest in facilitating the learning process through effective and suitable library services.

We can talk to each other. We can listen to each other. We have a basis for understanding. And it is in that kind of climate that we move into this era with the conviction that what we shall do is difficult, but more important, it is essential, and it is time it was done. 